\title{
THE EFFECT OF TRAINING IN IMPROVING THE COMMUNITY HEALTH WORKER SKILLS IN BREASTFEEDING PRACTICE AND INFANT DEVELOPMENT STIMULATION
}

\author{
Siti Hamidahi,2), Bhisma Murti3), Harsono Salimo4), Sri Mulyani5) \\ 1)Faculty of Health, University of Muhammadiyah Gresik, East Java \\ ${ }^{2)}$ Doctoral Program in Public Health, Universitas Sebelas Maret \\ 3) Masters Program in Public Health, Universitas Sebelas Maret \\ 4)Department of Pediatrics, Dr. Moewardi Hospital / \\ Faculty of Medicine, Universitas Sebelas Maret \\ 5)Diploma IV of Midwifery, Universitas Sebelas Maret
}

\begin{abstract}
Background: Community health centers in Indonesia have established community health workers (CHWs) to improve access and quality of health services available for the community. The CHWs are trained to run the integrated health posts (posyandu) in every hamlet. Training of the CHWs is expected to improve the quality of various health services, including exclusive breastfeeding support for lactating mothers. This study aimed to examine the effect of training on increasing the CHW skill in breastfeeding practice and infant development stimulation.

Subjects and Method: A quasi experiment before and after intervention with no control design was carried out in Gresik, East Java, from April to September 2019. A sample of 25 CHWs was selected for this study by quota sampling. The dependent variables were skills in (1) exclusive breastfeeding practice and (2) child development stimulation. The independent variable was training. The data were collected through questionnaire and observation. Mean score of skills before and after training was measured by paired t test.

Results: Mean score of exclusive breastfeeding practice after training (Mean=87.40; $\mathrm{SD}=1.32$ ) was higher than before training (Mean= 54.32; $\mathrm{SD}=2.43$ ), and it was statistically significant $(\mathrm{p}<0.001)$. Mean score of child development stimulation after training (mean=92.8; $\mathrm{SD}=0.71$ ) was higher than before training (mean $=63.8 ; \mathrm{SD}=2.22)$, and it was statistically significant $(\mathrm{p}<0.001)$.

Conclusion: Training is effective in improving skills of CHWs in exclusive breastfeeding practice and infant development stimulation.
\end{abstract}

Keywords: exclusive breastfeeding, child development, training, community health workers

\section{Correspondence:}

Siti Hamidah. Faculty of Health, University of Muhammadiyah Gresik, East Java, Indonesia. Email: siti_hamidahtw@student.uns.ac.id. Mobile: 081553520203

\section{BACKGROUND}

The agenda of sustainable development in 2030 are; 1) ending poverty and a healthy environment, 2) managing natural resources, 3) a prosperous life, 4) a peaceful society, 5) a strong global partnership. In connection with the agenda mentioned above, it is important to prepare quality Human Resources (HR) (Sustainable Development, 2015).

Quality human resources must begin in pregnancy, childbirth, and infancy. The first thousand days of life is a critical period, nutrition becomes important, brain growth experiences rapid development, will determine the quality of short-term and long-term life (Santrock, 2007).

Breast Milk (ASI) influences the development of early whitematter and brain meylin, effectively increasing children's cognitive understanding (Krameretal, 2008; Silversetal, 2012; Queglyetal, 2012; Deonietal, 2013; Benardetal, 2013). Breast milk is the most perfect food for babies during the first two years and there is no recommended sub- 
stitute, breastfeeding has so many health benefits for both mother and baby during lactation and in the future (Alimoradi, 2014).

In Al Qur'an (Al-Baqorah: 233) it is stated that mothers should feed their children for 2 years to complete the period of breastfeeding. WHO recommendations (2003), are; 1) Give early breastfeeding initiation and exclusive breastfeeding, 2) Give complementary food for breast milk (MPASI) at the age of 6 months, and continue breastfeeding for up to 2 years. While the WHO recommendations (2013); mothers must be given counseling and support for exclusive breastfeeding.

Exclusive breastfeeding in Indonesia and other countries has not reached the 80\% target. According to UNICEF (2017), the average coverage of exclusive breastfeeding in the world in 2015 was $46 \%$, in 2016 it decreased to $38 \%$. Coverage of exclusive breastfeeding in Indonesia has decreased which was; 2015 (55.7\%), 2016 (29.5\%), and 2017 (35.73\%).

Impacts of not giving ASI include; (1) Babies become easily sick, namely respiratory infections, gastrointestinal tract and diarrhea (Spauldingetal, 2009; Silversetal, 2012). (2) Obesity (Ibrahimzadekaretal, 2012; Cartagenaetal, 2014), (3) Incidence of Diabetus and Hypertension (Gundersonetal, 2008; Mayer et al, 2008; Villegasetal, 2008; Stuebeetal, 2009; Schwarz etal, 2010;). (4) Incidence of Asthma and Allergies (Schnooyietal, 2012; Silversetal, 2012). 5) Breastfeeding is effective in improving children's cognitive understanding (Krameretal, 2008; Quigleyetal, 2012; Bernard etal, 2013). 6) Malnutrition that occurs during the first 1000 days of life will have a severe and irreversible impact (Syarif et al., 2015).

According to Rollins et al. (2016), breastfeeding support requires action at various levels, start from policies, attitudes, social norms, and optimal services. Breast- feeding challenges, including; (1) Promotion of strong breastmilk, including saving lives and money, (2) Positive attitude towards breastfeeding (adequate breastfeeding facilities), (3) Enforce laws relevant to the breast milk substitute industry, (4) Monitor interventions using interventions tested and effective, (5) Political institution authorities pay attention to children's rights and women's health.

There have been many studies conducted on breastfeeding support to increase the duration of exclusive breastfeeding, but the coverage of exclusive breastfeeding is still unable to reach the expected target. For this reason, other intervention support studies are needed. The purpose of this study is to provide Aisyiyah cadre training on breastfeeding, breastfeeding and stimulation. In addition to knowing the effect of Aisyiyah cadre training on cadre skills in providing breastfeeding practices to nursing mothers.

\section{SUBJECTS AND METHOD}

\section{Study Design}

The method used was the design before and after with Control. Study sites was in the Cerme Health Center, Dadap Kuning, Benjeng, and Metatu, Gresik Regency, East Java. This study was conducted in April to September 2019. The training was carried out for 4 days, held at the Faculty of Health, University of Muhammadiyah Gresik.

\section{Population and Sample}

The population in this study were Aisyiyah nursing cadres totaling 170 people. A sample of 25 people was selected by quota sampling.

\section{Study Variables}

The dependent variable is cadre skills in providing breastfeeding practice and infant stimulation skills. The independent variable is training.

\section{Definition of Study Operational}

Cadre skills in providing breastfeeding practices are the behavior of Aisyiyah cadres 
which are expressed in the form of actions, namely the practice of breastfeeding properly. The skills of infant development stimulation were Cadre Aisyiyah's behavior which was expressed in the form of actions, namely the practice of stimulation of infant development.

\section{Study Instruments}

Data were collected using a questionnaire to measure cadre skills about correct breastfeeding and stimulating baby development skills.

\section{Data Analysis}

Univariate analysis is used to describe the characteristics of continuous data samples and categorical data. Bivariate analysis was used to compare cadre skills before and after training using the t test.

\section{Study Ethics}

This research was conducted with the approval obtained from the Health Research Ethics Committee of the Faculty of Medicine, Universitas Sebelas Maret, Surakarta, with number: 424 / UN27.6 / KEPK / 2019.

\section{RESULTS}

Table 1 showed that the average cadre knowledge of breastfeeding before training was 60.2 , the lowest score was 40 , and the highest score was 80 . The average cadre knowledge about infant stimulation before training was 63.8 , the lowest score was 50 , and the highest score was 85 . The average value of breast care skills before training was 47, the lowest score was 30, while the highest score was 78 . The average score of breastfeeding skills properly before training was 48.8, the lowest score was 37 and the highest score was 67 . The average score of breastfeeding skills before training was 38.96 , the lowest score was 29.67 , while the highest score was 67 . The average score of infant stimulation skills was o - 3 months, before training was 47.42, the lowest score was 36 , and the highest score was 77 . The average score of infant stimulation skills 0 - 6 months, before training was 36.44 , the lowest score was 31.25 , while the highest score was 67.

Table 1. Sample Characteristics (continuous data)

\begin{tabular}{|c|c|c|c|c|c|}
\hline & Variables & Mean & SD & Min & Max \\
\hline 1. & Age (years old) & 38 & 7.81 & 27 & 56 \\
\hline 2. & $\begin{array}{l}\text { Knowledge of breastmilk and } \\
\text { breastfeeding }\end{array}$ & 60.2 & 9.05 & 40 & 80 \\
\hline 3. & $\begin{array}{l}\text { Knowledge of infant } \\
\text { stimulation }\end{array}$ & 63.8 & 11.11 & 50 & 85 \\
\hline 4. & Breast care skills & 47 & 16.64 & 30 & 78 \\
\hline 5 . & Proper breastfeeding skills & 48.8 & 8.73 & 37 & 67 \\
\hline 6. & Breast milking skills & 38.96 & 12.15 & 29.67 & 67 \\
\hline 7. & $\begin{array}{l}\text { Developmental stimulation } \\
\text { skills of the baby aged o - } 3 \\
\text { months old }\end{array}$ & 47.42 & 12.07 & 36 & 77 \\
\hline 8. & $\begin{array}{l}\text { Developmental stimulation } \\
\text { skills of the baby aged } 3-6 \\
\text { months }\end{array}$ & 36.44 & 7.23 & 31.25 & 67 \\
\hline
\end{tabular}


Table 2. Sample characteristics (categorical data)

\begin{tabular}{lccc}
\hline \multicolumn{1}{c}{ Characteristics } & Category & Frequency & Percentage \\
\hline Age & $20-35$ yo & 10 & $40 \%$ \\
Level of education & $>35$ yo & 15 & $60 \%$ \\
& HS & 17 & $68 \%$ \\
\multirow{3}{*}{ Employment } & College & 8 & $32 \%$ \\
\multirow{3}{*}{ Number of children } & & & \\
& Working & 5 & $20 \%$ \\
& Not working & 20 & $80 \%$ \\
& 1 child & 2 & $52 \%$ \\
& 2 children & 13 & $40 \%$ \\
\hline
\end{tabular}

Table 3. Cadre skills before and after training

\begin{tabular}{|c|c|c|c|c|}
\hline & Variables & Mean & SD & $\mathbf{p}$ \\
\hline \multirow[t]{3}{*}{1.} & $\begin{array}{l}\text { The practice of exclusive } \\
\text { breastfeeding }\end{array}$ & & & \\
\hline & Before training & 48.8 & 8.73 & $<0.001$ \\
\hline & After training & 91.28 & 5.46 & \\
\hline \multirow[t]{3}{*}{2.} & $\begin{array}{l}\text { Baby developmental } \\
\text { stimulation skills }\end{array}$ & & & \\
\hline & Before training & 56.28 & 9.78 & $<0.001$ \\
\hline & After training & 85.28 & 2.47 & \\
\hline
\end{tabular}

Table 3 showed the results of data analysis using the test, which was the average score of breastfeeding practice exclusively after training $($ mean $=91.28 ; \mathrm{SD}=5.46)$ was higher than before training (mean $=48.8 ; \mathrm{SD}=8.73$ ), and statistically significant $(\mathrm{p}<0.001)$. Furthermore, for infant developmental stimulation skills, it showed that the average score of infant developmental stimulation skills after training (mean $=85.28 ; \mathrm{SD}=2.47)$ was higher than before training ( $m e a n=56.28 ; \mathrm{SD}=$ 9.78), and statistically significant ( $\mathrm{p}<0.001)$.

At the time of the training, Aisyiyah cadres could follow the explanation and practice carefully and enthusiastically, seemed happy to participate in learning about breastfeeding and stimulation, besides breastfeeding material related to religion really touched the cadre's feelings, because breastfeeding was mandatory and breast milk was a miracle given by Allah SWT who God willing, as a mercy and blessing. Aisyiyah cadres were able to provide learning in a workshop on breastfeeding and stimulation for pregnant women held in the areas of Cerme, Dadap Kuning, Benjeng and Metatu Health Center in June 2019.

\section{DISCUSSIONS}

The results of study indicated that the average value of exclusive breastfeeding practice and the average score of infant developmental stimulation skills after training was higher than before training, thus knowledge about breastfeeding, stimulation and lactation management must be given to the community. Due to the tight workload of health personnels, the support of Aisyiyah cadres needs to be continued in other places, including support from other women's organizations such as FWE (Family Welfare Empowerment), Muslimat, Fatayat and others. 
Alamirew et al. (2017) in Ethiopia stated that $69.8 \%$ of breastfeeding mothers have good knowledge and 30.2\% have bad knowledge. Maternal and child health service personnel must evaluate the maternal knowledge and attitude at each visit. According to Zhangetal (2018), breastfeeding knowledge was the most important factor towards exclusive breastfeeding behavior, giving mothers the opportunity to positively impact women's attitudes to exclusive breastfeeding.

Vijayalakshmi et al. (2015) stated that conducting interventions increased the knowledge of early breastfeeding initiation and the practice of exclusive breastfeeding was important. Mothers agreed that with colostrum (96.7\%), understanding baby's immunity was important (99.2\%), mothers agreed to answer exclusive breastfeeding was given during the first 6 months (85.2\%), 68\% of mothers stated that breastfeeding must be continued for up to 2 years (68\%), mothers understood the importance of belching after each meal (91.8\%), mothers understood to eat healthy foods (98.4\%), and mothers agreed that breastfeeding helped the mother and child bond (97.5\%). This indicated that mothers have good knowledge about breastfeeding, however, exclusive breastfeeding was still low.

Health service providers played an important role in education and encourage mothers to start and carry out breastfeeding continuously (Spatzetal, 2015). In this view, adequate training from health care providers seems to be required to support the practice of successful breastfeeding. In particular, mothers supported by staff trained according to WHO standards significantly extend the duration of breastfeeding (Hunter et al., 2015).

Breastfeeding must be supported by all mothers. Based on the results of positive data from public awareness campaigns in various countries in the world, the existence of optimal training for doctors, midwives and the provision of adequate facilities, can provide breastfeeding support. The results of the analysis explained that health care providers have an important role in providing education and encourage mothers to plan and breastfeed the baby. In this case, adequate training for health care workers appears to be mandatory to support breastfeeding. In addition, adequate facilities are needed to promote and support breastfeeding (Burgioetal, 2016).

According to WHO/Unicef (2007), the ten steps of the Baby Friendly Hospital Initiative (BFHI) initiative to promote breastfeeding success must be maintained and implemented, because the coverage of exclusive breastfeeding is still low. The ten steps include (1) Having a written breastfeeding policy that is routinely communicated to all health workers; (2) Train all health care staff with the skills needed to implement this policy; (3) Inform all pregnant women about the benefits and management of breastfeeding; (4) Help the mother to start breastfeeding within half an hour after birth; (5) Teach the mother how to breastfeed, and how to keep breastfeeding even if they have to be apart. (6) Give a newborn baby without food or drink other than breast milk, unless medically necessary treatment; (7) Inpatient care-i.e. allow mother and baby to stay together - 24 hours a day; (8) Encourage breastfeeding on demand; (9) Do not give pacifiers or artificial teats (also called dummies or soothers) to breastfeed babies; (10) Promote the formation of support groups for breastfeeding and refer their mothers out of the hospital/labor place.

The workload of labor service workers at Muhammadiyah Gresik Hospital, East Java, Indonesia is very dense, monitoring of nursing mothers is very limited, so it needs collaboration with breastfeeding support groups (Hamidah and Rulihari, 2017). 
Support groups for breastfeeding religious women's organizations are important.

Knowledge about breastfeeding and lactation management was still not widely known by the public, so it was important to disseminate it to the community. Counseling was done so far from health workers, while health workers carry out so many service tasks. There should be support from women's organizations to be able to contribute in disseminating knowledge about breastfeeding, breastfeeding, and lactation management to increase exclusive breastfeeding.

\section{ACKNOWLEDGEMENT}

The author would like to thank to the Aisyiyah cadres at the Cerme Health Center, Dadap Kuning, Benjeng, and Metatu, Gresik Regency, East Java, who have agreed to become study subjects.

\section{REFERENCES}

Alamirew MW, Bayu NH, Tebeje NB, Kassa SF (2017). Knowledge and Attitude towards Exclusive Breast Feeding among Mothers Attending Antenatal and Immunization Clinic at Dabat Health Center, Northwest Ethiopia: A Cross-Sectional Institution Based Study. Nurs Res Pract. doi: 10.1155/2017/6561028.

Bernard JY, DeAgostini M, Forhan A, Alfaiate $\mathrm{T}$, Bonet $\mathrm{M}$, Champion $\mathrm{V}$ (2013). Breastfeeding duration and cognitive development at 2 and 3 years of age in the EDEN mother-child cohort. J Pediatr; 163(1): 36-42.

Burgio MA, Lagana

AS, Sicilia A, Porta RP, Porpora MG, Frangež HB, Diventi G, Triolo O (2016). Breastfeeding Education: Where Are We Going? A SystematicRevieu. Iran J Kesehatan Masyarakat, 45(8): 970-977. Cartagena DC, Ameringer SW, McGrath J, Jallo N, Masho SW, Myers BJ (2014).
Factors Contributing to Infant Overfeeding with Hispanic Mothers. JGO$\mathrm{NN}$; 43: 139-59.

Deoni SCL, Dean DC, Pirytinsky I, Muircheartaigh J, Waskiewicz N , Lehman K, Han M, Dicks H (2013). Breastfeeding and early white matter development: A cross-sectional study.Neuro Image; 82: 77-86.

Gunderson EP (2008). Breast-feedingand diabetes: Long-term impact on mothers and their infants. INH Public Access; 8(4):279-86.

Ibrahi MB, Abadi R (2012). The prevalence of obesity and its Relitionship with motherage, Birth Interval and type of milk Consumption in Childrenunder 5 years in Torkaman Seaport City. J Kerman Univ Med Sci. 19(4): 384-91

Kramer MS, Aboud F, Mironova E, Vanilovich I, Plat RW, Matush, Igumnov S, Fombone E etal (2008). Breastfeeding and Child Cognitive Development: New Evidence from a large randomized trial. Arch Gen Psychiatry;65(5): 578-84.

Mayer-Davis EJ, Dabelea D, Lamichhane AP, D'aguostino RB, JrLiase AD, Thomas J, etal (2008). Breast-feeding and type 2 diabetes in the youth of three ethnic groups: the SEARCh for diabetes in youth case-control study.Diabetes Care; 31(3): 470-5.

Quigley MA, Hockley C, Carson C, Kelly YJ, Renfrew MJ, Sacker A (2012). Breastfeeding is associated with improved child cognitive development: a population-based cohort study. J of Pediatr; 160(1): 25-32.

Rollins NC, Bhandari N, Hajeebhoy N, Horton S, Lutter CK, Martines JC, Piwoz EG, Richter LM, Victora CG (2016). Why invest, and what it will take to improve breastfeeding practices? Lancet, 387(10017): 491-504.

Santrock (2007). Child development. Texas 
Dallas. The McGraw-Hill CompaniesInc; XI(1).

Schwarz EB, Brown JS, Creasman JM, Stuebe A, McClure CK, Van Den Eeden SK (2010). Lactationand maternal risk of type 2 diabetes: a population-based study. Am J Med, 123(9): 863 e1-6.

Schnooyi S, Khalkhali HARI, Rahimi-Rad MH (2012). The Relationship between Duration of Breastfeeding and risk of Asthma in 2-8 years old children. Urmia Med J, 23(1): 1-6.

SDGs (2015). The 2030 Agenda for Sustainable Development. Retrieved from https://sustainabledevelopment.un.org /sdgs.

Silvers KM, Frampton CM, Wickens K, Pattemore PK, Ingham T, Fishwick D (2012). Breast feeding protects against current asthma up to 6 years of age. J Pediatr, 160(6): 991-6e1

Spaulding DM, Gore R (2009). Breastfeeding Self-Efficacy in Women of African Descent. J Obstet Gynecol Neonatal Nurs; 38(2): 230-43.

Spatz DL, Froh EB, Flynn-Roth R, Barton S (2015). Improving Practice at the Point of Care Through the Optimizati on of the Breastfeeding Resource Nurse Model. J Obstet Gynecol Neonatal
Nurs, 44 (3): 412-8.

Stuebe AM, Schwarz EB, Grewen K, RichEdwards JW, Michels KB (2009). Duration of lactation and incidence of type 2 diabetes. JAMA, 294(20): 260110.

Villegas R, Gao YT, Yang G, Li HT, Elasy T, Zheng W (2008). Duration of breastfeeding and the incidence of type 2 diabetes mellitus in the Shanghai Women's Health Study. Diabetologia, 51(2): 258-66.

Vijayalakshmi P, Susheela T, Mythili D (2015). Knowledge, attitudes, and breastfeeding practices of postnatal mothers: A crosssectional survei.Int $\mathrm{J}$ HealthSci; 9(4):364-374.

WHO (2003). Global strategy for infant and young child feeding. Retrieved from http://apps.who.int/iris/bitstream/han dle/10665/42590/9241562218.pdf?seq uence $=1$.

UNICEF (2007). Ten Steps of the BabyFriendly Hospital Initiativeto Promote Successful Breastfeeding: J Perinat Educ, 16(1): 79S-80S.

Zhang Z, Zhu, Zhang L, Wan (2016). What factors influence exclusive breastfeeding based on the theory of planned behaviour. Midwifery, 62: 177-182 